\title{
The Development of Children's Social-Emotional Competences: A Case Study in UNP's Labschool-Kindergarten, Padang Indonesia
}

\author{
Nurhafizah $^{\mathrm{a}}$, Azlina Moh.Kosnin ${ }^{\mathrm{b}}$ \\ ${ }^{a}$ Universitas Negeri Padang \\ bUniversitas Teknologi Malaysia \\ Corresponding e-mail: Nurhafizah_ismail87@yahoo.com
}

\begin{abstract}
Social emotional competencies students need to be developed as early as possible. The development of these competencies will be the initial foundation for students so that they make children who have emotional social intelligence later in life. For that teachers are required to be more creative in developing children emotional social competence. For example, by looking for methods for learning and fun, with habituation, and through exciting games. The purpose of this study is to see or observe how the development of social competence, emotional student at Pembangunan Lab school UNP kindergarten and what do the teachers in its development. The type of research is descriptive qualitative approach. The informants were teachers and students groups B Pembangunan Lab. School UNP kindergarten in Padang. B1 and B2 in the group with the number of children 30. Data collection techniques are observation, interviews and documentation then the data analysis using data analysis techniques Miles and Huberman by way of data reduction, data presentation and conclusion of the data obtained during the study. From observations done shows that the social emotional competencies students are still not developed as expected. This is evident from observations done with most students have not been able to fully exercise restraint, not yet fully be sportsmanship, cannot be responsible, not to be able to communicate positive, yet can work together and empathize with a friend. Those things are seen when the observations were made when students play and learn and interact in class and supported by interviews with teachers and students as well as documentation of results.
\end{abstract}

Keywords: Development, Social emotional competence, Students Kindergarten

\section{INTRODUCTION}

Human resource development is an important factor in the development of a nation and human resource development efforts should be a continuous process from an early childhood. Children are the future generation who have the potential to develop optimally, then the education provided must be in accordance with the stage of development (Yuliani, 2009).

Early childhood education is currently receiving critical attention in Indonesia. This can be seen with the Directorate General Early Childhood Education Non-Formal and Informal (Dirjen PAUDNI) which focuses its attention to children from birth to 6 years of age. Education at an early age is essential implemented since the beginning of the formation and development of the human personality (Israwati, 2012).

Kindergarten (TK) is one form of early childhood education that organizes early education for children aged 4 to 6 years (Education Act Republic of Indonesia No.20 tahun 2003 pasal 28). Based on this law, educational institutions kindergarten geared to the development of children in a holistic manner. Kindergarten is an important stage in the development of the existing potential in students and to develop various aspects of development. Kindergarten is one of providing education that emphasizes growth and physical development of motor, social competence, emotional, language and communication in accordance with the uniqueness and stages of development that will be passed by children, therefore kindergarten need creating a situation 
conducive educational that is capable of providing a sense of security, peace and fun for students because in kindergarten will be given stimulation, guidance, care and administration of learning activities that will hone the abilities and skills of students by creating the conditions and environment in which students can explore the appropriate with the experience they can gain by giving him a chance to know and understand the learning experience gained through observation, imitation and experiments carried out repeatedly and involving all potential and existing intelligence in children - children Kindergarten. Depdiknas (2009).

Most of forming the sides of students' social emotional intelligence actually formed during period kindergarten. Especially because at the age of four to six years when the kindergarten children sitting bench that is when they learn to communicate and get along with friends and environment. There are so many events, intrigue and moments that occurred during two years in kindergarten, and how they try to survive all the problems that were honed emotional intelligence. (Irawati Istadi, 2006).

Learning for children is done through play. By playing a child's ability to be better and more complex, channeling thoughts and deployment capabilities greatly influenced by chance and opportunities to interact with their environment, which blends into the results of a new experience. Experience is only obtained if they get more opportunities to play and interact with peers. In many ways kids play every activity, will increase knowledge and vocabulary will be more. Playing as an activity that has a practical, can be used as a medium to enhance certain abilities in children, Mayke S. Tedjasaputra (2003).

They do not have a model that can serve as an example in fostering social life, so often bring problems in socializing. Children who lack the social skills it is possible to be rejected by another colleague. Children who are not able to work, unable to adjust, unable to interact properly, cannot control themselves, unable to empathize, not able to abide by the rules and are not able to appreciate others will greatly affect the development of other children. Instead, terbinanya social skills in children will bring acceptance from peers, acceptance of the teacher, and success in learning.

Teachers have an important role in developing the potential of children, including in developing the social emotional competence. Only in sebahagian kindergarten, for example, the learning process is still centered on the teacher, the teacher in the learning activities to educate children to sit, silent and listeners. The process of learning activities with the concept of playing while learning and learning while playing looks just be a slogan. The learning process as this will invite some of the problems in the classroom as it is said Mustafah at Bachrudin (2005) : 1) If the role of the teacher is still dominant, children tend to be passive; 2) If the teacher is not willing to accept the update, create or choose a theme - the theme of the textbooks that have been standard, so that the child is less empathy, unmotivated, less social competence in solving problems in daily life - the day; 3 ) If there is any preparation in classical seating that tends to alienate one child with another, will make children less sociable and difficult to communicate with one another; 4) If the language and behavior, the teacher is not touching the emotions of children, the child will become stiff and hard to talk.

Emotional learning is of utmost importance, partly because the strength of a person's emotional impulse can be more powerful than the power of logic. That's because the brain logical thinking less rapidly with the emotional brain. What is meant by the emotional brain, is a part of the brain called the amygdala, the part of the proceeds in the form of action to respond emotionally. In some situations, the emotional brain responds in the form of an emotional reflex. If learning earlier negative emotions, he will also issue a negative reflex anyway. (Irawati Istadi, 2006).

Goleman (2016) states that man has at least two different intelligences, namely intellectual intelligence and emotional intelligence. Intellectual intelligence related to academic ability, but does not guarantee success in life. Success is the ability to determine and achieve personal goals and work. Based on Darmiyati Zuchdi (2010), the highest intellectual, he only contributed $20 \%$ to the factors that determine success in life, $80 \%$ filled by other things that emotional social intelligence. Social intelligence emotional and intellectual intelligence must be in balance. Intellectual intelligence without emotional social intelligence does not produce anything.

If a child is taught social emotional competencies will be able to establish good relationships with the surrounding environment. Kids as children who have high emotional social competence, will get a good social acceptance, whereas children who have low emotional social competence tend to have unfavorable social acceptance. Social emotional competence is something that must be understood and taught, because children are social beings who will live and 
adapt to the surrounding environment. (Andi Agusniatih, 2015).

Following Glatt (2000) stated that social competence, emotional need to be developed for children because it has benefits, namely: control conflicts and differences in a more constructive manner, where children practice in controlling his emotions, provide a more effective response against undesired behavior, make better decisions good, and develop healthy relationships with others. Things are generally taught in socio-emotional competence is to make friends, understand and express emotions themselves or others. Increasing attention and listen, accept responsibility, develop the ability assertive and self-concept, learning strategies effective problem solving, collaboration, and give a positive response to criticism and ridicule.

Teacher is one of the important factors for the realization of the development of kindergarten children. The ability of teachers to understand, detect, and stimulate the development of social competence, emotional has a very important role. The importance of mastering the competence of teachers is understandable, considering the development potential of children experiencing barriers in interacting with the environment, either by peer environment and the wider environment. Children who are not able to overcome these social barriers possible impact on other aspects of development. In this context, the use of various strategies, methods, and stimulation of the game, actually has a meaning therapeutic or healing of various social barriers experienced by children, (Agus Mulyadi, 2013).

Based on these problems the study was designed to determine how the child's emotional development of social competence in Pembangunan Lab school UNP kindergarten. In particular, the question that will be answered in this study is: How is the implementation of learning in developing the social emotional competence of children in Pembangunan Lab School UNP Padang kindergarten.

\section{LITERATURE REVIEW}

Emotion is an important factor in human life. Emotion is an aspect that can seep into human existence, related practically too all human behavior like action, perception, memory, learning or in making decisions, (Djohan, 2010). Johnson and Johnson specifies that social emotional competence is a skill to establish and maintain positive relationships with others, attitudes, motivations others about what was said and done, and the skills to communicate clearly and effectively, and the skills to build effective relationships and cooperative. (David W. Johnson and Roger T. Johnson, 1999).

Carol Seefelt \& Nita Barbour (1994), stated that the development of social competence, emotional can be done through games and social interaction. Including through: 1) explain the concepts and behaviors that must be done; 2) discuss the ideas and behavior of the children and asked them about the ways that can be selected to connect with other people; 3 ) Practicing social emotional competence, where children practice various concepts of behavior in a real situation.

The age range between 4 to 6 years old is one of the early age ratings that were in kindergarten, one of the educational institutions, formal education, as stipulated in the Law on National Education System Number 20 of 2003 paragraph 3. Depdiknas (2004). This age is a sensitive period which is very important for a child's education at that time, the forging of a strong will give the former child later in life. Errors in developing children have long-term negative effects that are difficult to fix.

Law of the Republic of Indonesia number 20 of 2003 on the system of national education in Article II, paragraph 14 says early childhood education is: A development efforts aimed at children from birth to the age of six years are accomplished by providing stimulation of education to help the growth and development of the physical and spiritual so that children have readiness in entering further education. As expressed by Freud in Heni (2010) that early childhood is a time that determines a major effect on the development of life, and a person's personality is determined from an early age (0-5 years).

The goals to be achieved in early childhood education is to create an environment and conducive educational, democratic and comparative so that all potential and dimensions of the existing development in the child can develop optimally, and the organization of early childhood education can help children develop various potentials whether physical, emotional, social, and cognitive, (Sue Bredekamp, 1987). Psychologists Turner and Helmes in Heni (2010) said that "Playing has a considerable influence on social development and the child's personality, play a meaningful activity and help the children relate to the environment around them, play also shows the character of the child". Syaodih (2002) said that social development 
in childhood lasts through relationships between friends in the various forms of the game.

Indicators of social competence of emotions in play activities described into 7 aspects: 1) skills in collaboration, 2) skill in adjusting, 3) skills in interaction, 4) skills in self-control, 5) skills in empathy, 6) skills in keeping rules, and 7) skills in respect of others. The findings in the field of activity in the form of playing the students, described to then analyzed using seven indicators, so they will know how a child's emotional development of social competence in learning.

\section{RESEARCH METHODOLOGY}

This research was conducted in kindergarten in the desert town of kindergarten Lab school Pembangunan UNP Padang in group B. The study was conducted over three months, from July to September 2015, which is about the implementation of the development of social emotional competence of children in learning. This study uses qualitative descriptive study aims to describe things or phenomena as their circumstances involving the research team as an observer and student of the research results, the teacher as the primary data source, as well as the implementation of learning documents and interviews with children as secondary data.

The method of data collection in qualitative descriptive study approach interviews, collected documents relating to the situation as well as photographs of the implementation of learning, observation notes, a description of the meeting. The data have been obtained and processed by means of qualitative techniques developed by Miles and Huberman.

\section{RESEARCH RESULT}

Based on observations and data analysis learning activities in Lab school Pembangunan UNP kindergarten of Padang, running well. It is seen from the additional planning and execution of daily activities. But teachers tend to focus more academicoriented activities and was rather impressed override the needs of a child's play. Teachers tend to be chasing the target-oriented curriculum of academic activities, this occurs by reason of the limited time, and so forth. This is also reinforced by the results of interviews conducted on the teacher.

From observations made visible the teacher did not involve children in the planning of learning. Teachers prepare Kegian Daily Plan with separate activities (no alignment). In the implementation of teacher learning is already acting as facilitators and mentors, is seen when the teacher came and toured supervise children when doing a given task. Learning activities in the classroom have tended in academic monotonous routine.

Further observations were made at each meeting did not look at all special activities to develop social emotional competence. The development of social competence, emotional just linked in a variety of learning activities only. Teacher gives reason because they do not have some kind of specific guidance modules so that they do not conduct special activities to develop social emotional competence. Besides, they also have argued that the time available is not sufficient for it because many aspects of the capabilities that must be developed and they are limited because of a narrow time and inability to supervise the child in an amount not less.

In any observations made when the teacher observation tend not maximize the use of the game. Plaything in the room (indoor) in addition to inadequate amount according to the number of children, game tools are also often stored so that children cannot use to play. Teachers are more likely to perform routine activities that are academic to develop the ability to read, write and count. While the need for children to play. The principle of playing while learning and learning while playing seems just a slogan. And if it is done would be the more potential that can be developed especially children social emotional competence. Because through play children will learn restraint, learn to wait their turn, to empathize, to learn responsibility, adaptability, collaboration and others. Upon further analysis, it may be due to lack of knowledge and experience and commitment of teachers about the importance of the development of social emotional competence of children from an early age.

However, from the observations made, the kindergarten play area is quite extensive, but not taken to the maximum teacher, both from the provision of a more complete and from his own play activities. Teachers only give children the opportunity to play in a short recess the use of games that already exist. She was never seen taking children play traditional games for example. Where as the play area is so vast, it is suitable if the traditional game Indonesia was held in the kindergarten. Where the traditional game is said to also contain elements that can help the development of social competence, emotional. 
Found some children come late and go to class when the hours of study already begun. There also were late arriving in the morning but immediately took the front row while slightly pushing his friend, despite being reprimanded by the teacher the child does not want to listen and succumb. Learning activities in the classroom are also more likely monotonous. Often some of the kids are bored, do not want to do the job completely, preferring a walk while teaching hours and also interfere with her friends, even cried because I could not work and would like to go home. Seen No child wants to share but some are not. Some like to play alone and did not want to get involved early in collaboration with his colleagues but there is also a play, berlin-runoff with friends. In speaking found children who like to talk rude to friends and some even arguing, shouting and hitting his friend, sometimes seen children were fighting over a toy. Hours of play they are very narrow. The children were so excited when the break arrived. They quickly scattered and romp out of the classroom. Scramble got on the board slides, swings, teeter totter, globes and so forth.

Here it does not look special activity that is used to develop children's emotional and social competence is also no specific guidance about it. From interviews with teachers, they stated that the development of social competence emotions are no special activities, but the competency alone is associated with a variety of activities are there, so some sort of hidden curriculum. In doing activities such as teachers get children to get used to queuing, no scrambling, no teasing, and so forth.

From the interviews conducted in children, most of them have working parents, they rarely have the time to play with their parents. Kids often play yourself at home, parents tend to like to buy toys and facilitate the child in play using a high-tech games and did not consider the implications for the development of social competence of children's emotions further. They think that is important children sitting quietly at home, do not go anywhere when home from school. Whereas tool - a toy he bought for children often bring a negative impact, especially for the development of children's emotions social competence.

\section{CONCLUSIONS}

Based on the results of research and discussion that has been described, it can be concluded that:

1. Planning made the teacher has not shown that social emotional competence is one of the capabilities that are developed in the learning activities, but are only associated in various activities no special activity to it.

2. In the implementation of learning activities teachers do not have some kind of specific guidance modules on child's emotional development of social competence

3. Seen from a variety of activities that do not yet have the social competence of children of emotions as social characteristics that must be their own emotion.

4. Parents in the house likes to buy toys and facilitate the child in playing the game of hightech and less into account the implications for the development of social competence of children's emotions further.

Parents and teachers have an important role in emotional develop the social competence of children from an early age. These competencies should be developed as early as possible in preparation for the child to their future as members of the community are expected to someday bring benefits to the environment. Children need to have the ability to cooperate, able to adapt, interact in a positive, able to control themselves, are able to develop empathy towards friends, have the ability to comply with the rules and be able to appreciate others, all of which it is the capital of its role as a social creature.

From this conclusion it is suggested that (1) Parents need to pay more attention to children, providing adequate and quality time with the child, selective in providing tools for the game and know the negative impact of advanced equipment and high-tech game for the development of social competence of their long term emotional. (2) Teachers need to be more committed and creative in developing social competence children's emotions. Teachers need to establish cooperation or collaboration with the parents in order to develop social competence of children's emotions.

\section{REFERENCES}

Agusniatih, Andi. 2015. Disertasi. Jakarta: PPs UNJ Berk., Laura. E. 2003. Child Development. Boston: Pearson International Edition

Bennett, N., Wood, L. \& Rogers, S. (1997). Teaching through play: Teachers' thinking and classroom practice. Buckinghum: Open University Press.

Depdiknas. 2009. Peraturan Menteri No. 58 tahun 2009 tentang Penyelenggaraan PAUD. Jakarta: Depdiknas.

Depdiknas. 2009. Standar Pendidikan Anak Usia Dini. Jakarta: BSNP 
Djohan. 2010. Respons Emosi Musikal. Bandung: Lubuk Agung.

Goleman., Daniel. 2006. Emotional Intelligence, terjemahan cetakan ke 22. Jakarta: PT. Gramedia Pustaka Utama

Hurlock, Elizabeth. G. 1997. Perkembangan Anak Jilid I. Jakarta: Erlangga

Istadi, Irawati. 2006. Melipat gandakan kecerdasan emosi anak. Bekasi: Pustaka Inti.

Israwati. 2012. Disertasi. Jakarta: PPs UNJ

Mulyadi, Agus. 2013. Disertasi.

Moleong, Lexy. J. 2004. Jurnal Pendidikan Anak Usia Dini, 'Teori dan Aplikasi Kecerdasan Jamak/Multiple Intelligence. Jakarta: PPs UNJ.

Santrock., John. W. 2007. Perkembangan Anak, alih bahasa edisi kesebelas jilid 2. Jakarta: Erlangga.

Seefeldt, C. \& Barbour, N. (1998). Early chidhood education: An introduction (4th ed). Ohio: Merrill Publishing Company.

Slavin., Robert. E. 2008. Psikologi Pendidikan; Teori dan Praktek, terjemahan Marianto Samosir. Jakarta: PT. Indeks.

Syaodih, Nana. (2005). Metode Penelitian Pendidikan. Bandung: Rosdakarya

Sujiono, Yuliani Nurani. 2009. Konsep Dasar Pendidikan Anak Usia Dini. Jakarta: Indeks

Sugianto Tedjasaputra., Mayke. 2007. Bermain, Mainan dan Permainan. Jakarta: Fakultas Psikologi Universitas Indonesia

Zain., Ahmad. 18 Februari 2012, http://edukasi.kompasiana.com/2012/02/18/sto p-fenomena-anak-di-bawah-umur-melanggarhukum/, Jakarta: Kompasiana

Zuchdi, Darmiyati. 2010. Humanisasi Pendidikan Menemukan Kembali Pendidikan Yang Manusiawi. Cetakan ketiga. Jakarta: Bumi Aksara. 